\title{
Anthocyanins content of methanol extract of parijoto (Medinilla speciosa) and its effect on serum malondialdehyde (MDA) level of hyperlipidemic rat
}

\author{
NOOR NAILIS SA’ADAH`, ADEK MAYANG INDIANI, AWIK PUJI DYAH NURHAYATI, \\ NOVA MAULIDINA ASHURI \\ Department of Biology, Faculty of Science, Institut Teknologi Sepuluh Nopember. Building H, ITS campus, Sukolilo, Surabaya 60111, East Java, \\ Indonesia. Tel./fax. +62-31-596 3857. `email: nailis@bio.its.ac.id.
}

Manuscript received: 11 February 2019. Revision accepted: 24 May 2019

\begin{abstract}
Sa'adah NN, Indiani AM, Nurhayati APD, Ashuri NM. 2019. Anthocyanins content of methanol extract of parijoto (Medinilla speciosa) and its effect on serum malondialdehyde (MDA) level of hyperlipidemic rat. Nusantara Bioscience 11: 112-118. Parijoto (Medinilla speciosa) is an endemic plant in Indonesia that its fruit have a purplish red color, which indicated that parijoto fruits contain anthocyanins, pigments of the flavonoid class that responsible for the red, blue and purple coloration of many flowers and fruits. This study was aimed to determine the total yield of extract and anthocyanins content of methanol extract of parijoto (Medinilla speciosa) pericarp and whole fruit and the effect of parijoto whole fruit extract on serum malondialdehyde (MDA) level of the hyperlipidemic rats. Extraction of parijoto fruit and pericarp were carried out by the maceration method with methanol as a solvent. Determination of the total anthocyanin was done by $\mathrm{pH}$ difference method. MDA serum levels were done in a pre-test and post-test Randomized controlled group design was used in this study. Rats were divided into five groups: normal rats, hyperlipidemic rats, hyperlipidemic rats treated with methanol extract of parijoto $\left(500 \mathrm{mg} \cdot \mathrm{kg}^{-1}, 1000 \mathrm{mg} \cdot \mathrm{kg}^{-1}\right.$, and $1500 \mathrm{mg} \cdot \mathrm{kg}^{-1}$ body weight). Blood was collected at hyperlipidemia state and after treatment of methanol extract of parijoto for determination of MDA level in blood serum. The results showed that the total yield of parijoto pericarp extract and the whole fruits were $11.46 \mathrm{~g}(3.18 \%)$ and $9.02 \mathrm{~g}(2.88 \%)$ respectively. Anthocyanins content of parijoto pericarp and whole fruit extracts were $208.75 \mathrm{mg} \cdot \mathrm{L}^{-1}$ and $173.7 \mathrm{mg} \cdot \mathrm{L}^{-1}$. Administration of methanol extract of whole fruit parijoto in hyperlipidemic rats reduced serum MDA levels significantly $(\mathrm{p}<0.01)$, from $14.88 \mathrm{nmol}^{-1} \mathrm{~mL}^{-1}$ to $8.63 \mathrm{nmol} \cdot \mathrm{mL}^{-1}$.
\end{abstract}

Keywords: Anthocyanins, hyperlipidemia, MDA, Medinilla speciosa, parijoto

\section{INTRODUCTION}

Indonesia is one of the three global megadiverse countries (Indonesia, Malaysia, and the Philippines) in the Association of Southeast Asian Nations (ASEAN). The Indonesian archipelago comprises of two world's biodiversity hotspots (areas with high endemic species that are highly threatened by habitat loss), leading to the evolution of a megadiverse fauna and flora on the global scale. Biodiversity plays an important roles in traditional medicine, pharmacy, agriculture and economy along with environmental policies (Rintelen et al. 2017). Several species of flora in Indonesia have been widely used in healthcare systems. One of the endemic plants that have not been fully explored pharmacologically is parijoto (Medinilla speciosa) although it has been used as herbal medicinie. Pregnant women usually consumed parijoto and also used for diarrhea and cholesterol drugs (Tussanti et al. 2014).

Parijoto fruits has a purplish red color indicated that parijoto fruits contain anthocyanins. Anthocyanins are the most important group of water-soluble natural pigments that are responsible for the blue, purple, red and orange colors of many fruits and vegetables (Miguel 2011). Anthocyanins belong to a group of compounds known as flavonoids (Mazza 2007). There are 17 anthocyanidins found in nature, but only six (cyanidin, delphinidin, petunidin, peonidin, pelargonidin, and malvidin, with cyanidin) are the most common (Jaganath and Crozier 2010). Anthocyanins from various plant sources have been known to have beneficial effects on health for several chronic diseases (Kamiloglu 2015). Anthocyanins exhibit antioxidant activity, therefore, contribute to the heart disease prevention, cancer, inflammatory disease (Nakajima et al. 2004), and is very important in the human diet (Jaganath and Crozier 2010). Sa'adah et al. (2017; 2018) reported that methanol extract of parijoto reduced total cholesterol, atherogenic index, LDL-C, triglycerides and increase HDL-Cholesterol significantly $(\mathrm{p}<0.01)$. Another study reported that the methanol fraction of Parijoto has antioxidant activity with an $\mathrm{IC}_{50}$ value of 46.65 $\mu \mathrm{g} \cdot \mathrm{mL}^{-1}$, total phenolic content of $388 \mathrm{GAE} \cdot \mathrm{g}^{-1}$ extract and total flavonoid content of $164 \mathrm{RE} \cdot \mathrm{g}^{-1}$ extract (Wachidah 2013). Therefore, Parijoto has the potential as an antioxidant agent.

Antioxidants may inhibit the oxidation process, even at relatively small concentrations and also have diverse physiological roles in the body (Kumar 2014). There are two main groups of antioxidants in living cells: enzymatic antioxidants and non-enzymatic antioxidants. The non- 
enzymatic group of antioxidants contains several subgroups, vitamins (A, E, C), enzyme cofactors, minerals (zinc and selenium), peptides (glutathione), phenolic acids, and nitrogen compounds (uric acid) (Shebis et al. 2013). Antioxidants perform by delaying, preventing or removing oxidative harm to a target molecule (Banjarnahor \&Artanti 2014).

Maintaining the balance between antioxidants and reactive oxygen species (ROS) molecules is very important (Shebis et al. 2013) to prevent oxidative stress as the cause of several degenerative diseases. Supplementation of exogenous antioxidants is a promising way to overcome the undesirable effects of ROS induced oxidative damage. Flavonoids are the best exogenous antioxidants from the plant (Kasote et al., 2015). The antioxidant mechanism of flavonoids includes: (i) quenching free radical elements, (ii) chelating metal, (iii) suppressing the enzymes associated with the free radical generation, and (iv) stimulating of internal antioxidant enzymes (Banjarnahor and Artanti 2014). One method to predict the oxidative stress levels is the determination of MDA level in blood plasma. Malondialdehyde (MDA) is widely used as a biomarker for assessing oxidative stress in the biomedical fields; and determined by thiobarbituric acid (TBA) (Singh et al. 2014).

This study aims to determine the total anthocyanins content of the methanol extract of parijoto fruits (pericarp and the whole fruits) and its effect on malondialdehyde (MDA) level in serum of the hyperlipidemic rat. Parijoto is expected to be one of the alternative sources of exogenous antioxidants, as well as being an ingredient for functional food products. Functional food is defined as food products that have an additional positive health benefit, either in short and long term (Cencic and Chingwaru 2010).

\section{MATERIALS AND METHODS}

\section{Materials}

Parijoto (Medinilla speciosa) fruits were obtained from Muria Mountain, Kudus, Central Java, Indonesia; 2 months-old male Wistar rats (Rattus norvegicus) weighing 110-150 g were obtained from the experimental animal laboratory, Faculty of Pharmacy, Airlangga University, Surabaya, Indonesia. Basal feed for this study was commercial feed (broiler II, Comfeed ${ }^{\circledR}$ )., while high-lipid diet included reused cooking oil and duck egg yolk (ratio 2:1); methanol and $\mathrm{HCl}$ for extraction; $\mathrm{KCl}$ buffer $(\mathrm{pH}=1)$ and sodium acetate buffer $(\mathrm{pH}=4.5)$ for determination of total anthocyanin, TCA and TBA solutions for the measurement of MDA levels.

\section{Procedures}

\section{Extraction of anthocyanins}

Whole fruit and pericarp of parijoto were weighed, then ground using a blender. Extraction of anthocyanin pigments from parijoto whole fruits and pericarp were carried out using the maceration method. One hundred $g$ of parijoto whole fruits or pericarps were macerated with 500 $\mathrm{mL}$ methanol containing $1 \% \mathrm{HCl}$ with a ratio of $1: 5(\mathrm{~b} / \mathrm{v})$ at room temperature for 24 hours. The filtrate was filtered with filter paper (Qualitative Filter Paper $60 \mathrm{~cm} \times 60 \mathrm{~cm}$ ) and partitioned with diethyl ether using a separating funnel to separate the non-anthocyanin component, distilled water was added to increase the polarity of the solution, (volume ratio of filtrate: diethyl ether: distilled water $=1: 2: 1$ ) (Lestario et al. 2011).

\section{Determination of $\lambda$ maximum extract}

Determination of $\lambda$ maximum of parijoto extract was carried out by UV-Vis spectroscopic method. One $\mathrm{ml}$ of the parijoto fruit extract was dissolved in ethanol to $10 \mathrm{~mL}$; the absorbance of the mixture was measured at $\lambda$ 400-800 nm (Suzery et al. 2010).

\section{Determination of total anthocyanin by $\mathrm{pH}$ difference method (differential)}

The anthocyanin extract was dissolved in $\mathrm{KCl}$ buffer $(\mathrm{pH}=1)$ and also dissolved in sodium acetate buffer $(\mathrm{pH}=$ 4.5) with extract to buffer ratio $=1: 5(\mathrm{v} / \mathrm{v})$. The absorbance of the extract was measured at the wavelength of $510 \mathrm{~nm}$ and $700 \mathrm{~nm}$ after 15 minutes incubation at room temperature. The results were calculated using the following equation (Lestario et al. 2011):

$$
\boldsymbol{A}=\left(A_{510}-A_{700}\right) \mathrm{pH} 1,0-\left(A_{510}-A_{700}\right) \mathrm{pH} 4,5
$$

The total anthocyanin level of the extract was calculated by the formula:

$$
\text { Total Anthocyanin }\left(\frac{m g}{L}\right)=\frac{A \times B M x D F x 1000}{s x l}
$$

Where:

$\mathrm{BM}=$ Molecular weight of cyanidin 3-glucoside = $449.2 \mathrm{~g} / \mathrm{mol}$

$\mathrm{DF}=$ Dilution factor

$\varepsilon=$ Molar absorptivity of cyanidin 3-glucoside $=$ 26,900 L/(mol. cm)

$\mathrm{l}=$ Cuvette thickness $(1 \mathrm{~cm})$

\section{Hyperlipidemia treatment}

Hyperlipidemia rats were induced by administration of high lipid diet following a procedure from Sa'adah et al. (2017). Experimental rats were fed with a mixture of duck egg yolk and reused cooking oil (ratio 2:1) orally as much as $1 \%$ of body weight (BW) for $30 \mathrm{~d}$. Rats were weighed weekly. Four groups of rats (II-V) were treated with highlipid diet (hyperlipidemic treatment), and one group (a normal group) without hyperlipidemic treatment.

\section{Experimental animals grouping}

Rats ( $R$. norvegicus) were acclimatized for one week before treatment. Feed and drinking water was given in ad libitum. After the acclimatization period was completed, the rats were weighed and divided into five groups.

Group I: Negative control group, without hyperlipidemic treatment (Normal group), basal diet

Group II: Positive control group, hyperlipidemic treatment 
Group III: Hyperlipidemic group treated with $500 \mathrm{mg}$ parijoto whole fruit methanol extract $\mathrm{kg}^{-1} \mathrm{BW}$

Group IV: Hyperlipidemic group treated with $1000 \mathrm{mg}$ parijoto whole fruit methanol extract. $\mathrm{kg}^{-1} \mathrm{BW}$

Group V: Hyperlipidemic group treated with $1500 \mathrm{mg}$ parijoto whole fruit methanol extract. $\mathrm{kg}^{-1} \mathrm{BW}$

Ethical guidelines for the use of animals in research refer to Directive 2010/63/EU.

\section{Blood serum collection}

Blood collection was taken after the treatment of the methanol extract of parijoto. The blood serum was separated by centrifugation of blood cells at $3000 \mathrm{rpm}$ for $10 \mathrm{~min}$. Blood serum was collected in a $1.5 \mathrm{~mL}$ microtube.

\section{Measurement of MDA levels}

One hundred $\mu \mathrm{L}$ of blood serum was added with 2.45 $\mathrm{mL}$ TCA and $2.45 \mathrm{~mL}$ TBA and then heated with boiling water at $100{ }^{\circ} \mathrm{C}$ for 20 minutes. The blood serum was centrifuged for 10 minutes at $8000 \mathrm{rpm}$. The absorbance of the supernatant; $2.45 \mathrm{~mL}$ TCA and $2.45 \mathrm{~mL}$ TBA as a blank was measured at a wavelength of $530 \mathrm{~nm}$. Measurement of MDA levels was carried out using the MDA standard curve (Latifa 2015).

\section{Data analysis}

Data of MDA levels in blood serum were analyzed using ANOVA then continued using Tukey test at a significance level of $95 \%$.

\section{RESULTS AND DISCUSSION}

\section{The yield of anthocyanins pigment of parijoto fruit extract}

The extraction of anthocyanins pigments of parijoto fruits was done on the whole fruit and the pericarp. The pericarp of parijoto was done by removing the contents of the fruit and only a purplish red skin left. Further, the process of extract evaporation was done at relatively low temperatures because of the unstable structure of anthocyanin. The stability of anthocyanin is related to color, equilibrium forms and co-pigmentation, which affected by $\mathrm{pH}$, temperature, oxygen, light, ascorbic acid, nucleophilic agents, free sugars, sulfur dioxide and the presence of enzymes (Iacobucci and Sweeny 1983; Jackman et al. 1987; Francis 1989; Cabrita 1999; Jordheim 2007). By heating an anthocyanin solution, the equilibrium was driven towards the form of chalcone due to a decrease in the quantities of the colored flavylium cation form (Figure 3) (Jordheim 2007).

The yields of anthocyanin from the pericarp and whole fruit of parijoto were presented in Table 1. showed that the anthocyanin content of pericarp was higher than that of the whole fruit. The extract of the pericarp of parijoto was purplish-red powder which indicates that anthocyanin pigment is in the pericarp of parijoto. The extract yield of pericarp and whole fruit of parijoto were $3.18 \%$ and $2.88 \%$ respectively.

\section{Determination of $\lambda$ max}

The results of determining $\lambda \max$ for anthocyanin standardization presented in Table 2. Based on the results in Table 2, it showed that the maximum wavelength for measuring anthocyanin of parijoto extract was $545 \mathrm{~nm}$. According to Harborne (1958) anthocyanins have a range of visible spectrum regions at $475-550 \mathrm{~nm}$. The results in Table 2 indicated that parijoto extracts contain anthocyanin pigments. Juniarka et al. (2011) reported that the qualitative determination of anthocyanin was done by scanning at the wavelength of $200-750 \mathrm{~nm}$ to the dissolved sample in different pH of buffer solutions. Juniarka et al. (2011) also reported that anthocyanins produce typical peaks in the visible areas between $500-550 \mathrm{~nm}$ in acidic solution $(\mathrm{pH}$ 1.0 ), whereas at $\mathrm{pH} 4.5$, the peaks of anthocyanin were in the UV spectrum area between 250-350 nm (Figure 2).

\section{The total anthocyanins content of methanol extract of parijoto fruit}

Determination of anthocyanin was carried out by the $\mathrm{pH}$ difference method. The results showed that the total anthocyanins content of methanol extract of parijoto pericarp and whole fruit were 208.75 and $173.7 \mathrm{mg}^{-1} \mathrm{~L}^{-1}$ respectively. The anthocyanin pigments of pericarp were higher than the whole fruit of parijoto.

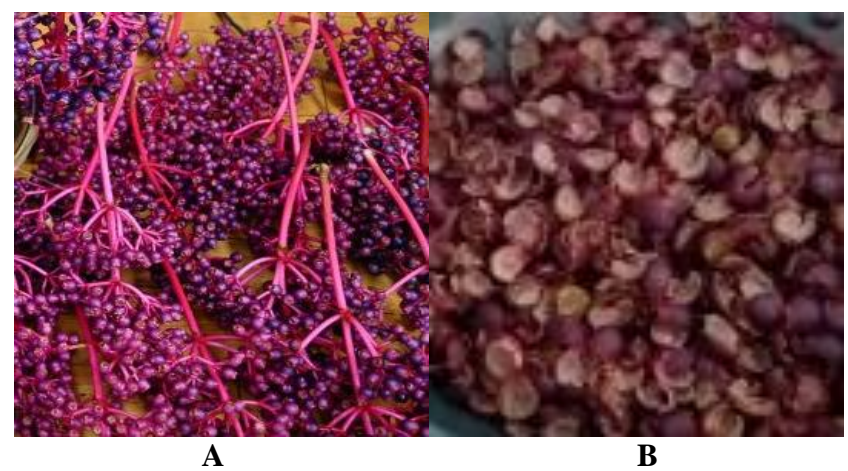

Figure 1. Parijoto fruits. Whole fruit (A), pericarp (B)

Table 1. The yield of anthocyanins pigment of parijoto fruit

\begin{tabular}{|c|c|c|c|c|c|}
\hline Extract & $\begin{array}{l}\text { Color of the } \\
\text { extract before } \\
\text { evaporation }\end{array}$ & $\begin{array}{l}\text { Color of the } \\
\text { extract after } \\
\text { evaporation }\end{array}$ & $\begin{array}{c}\text { Initial } \\
\text { weight } \\
\text { (g) }\end{array}$ & $\begin{array}{l}\text { Wight of } \\
\text { extract }(g)\end{array}$ & $\begin{array}{c}\text { Yield of } \\
\text { extract } \\
(\%)\end{array}$ \\
\hline Pericarp & Dark Red & $\begin{array}{l}\text { Purplish red } \\
\text { powder }\end{array}$ & 360.53 & 11.46 & 3.18 \\
\hline $\begin{array}{l}\text { Whole } \\
\text { fruit }\end{array}$ & Red & $\begin{array}{l}\text { Dark red } \\
\text { powder }\end{array}$ & 313.28 & 9.02 & 2.88 \\
\hline
\end{tabular}

Table 2. The absorbance of parijoto extract in various wavelength

\begin{tabular}{lccc}
\hline \multirow{2}{*}{ Extract } & \multicolumn{3}{c}{ Absorbance } \\
\cline { 2 - 4 } & $\mathbf{5 4 5} \mathbf{~ n m}$ & $\mathbf{6 5 5} \mathbf{~ n m}$ & $\mathbf{6 6 5} \mathbf{~ n m}$ \\
\hline Pericarp & 0.352 & 0.065 & 0.068 \\
Whole fruit & 0.195 & 0.048 & 0.046 \\
\hline
\end{tabular}



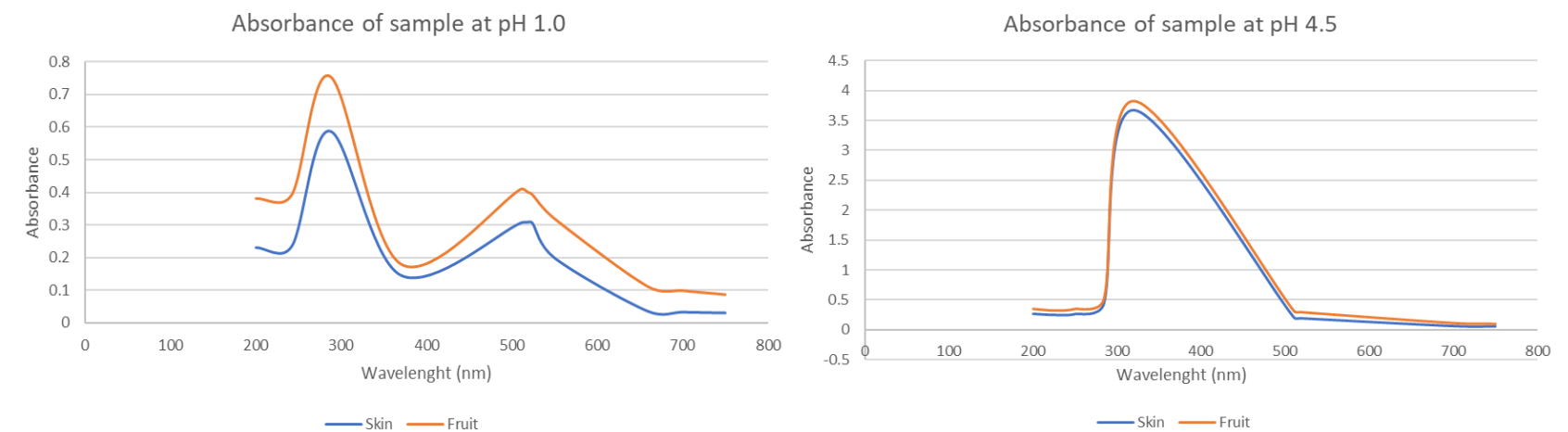

Figure 2. The spectrum of parijoto fruit extract in $\mathrm{KCl}$ buffer solution $\mathrm{pH} 1.0$ (A) and Sodium Acetate Buffer $\mathrm{pH} 4.5$ (B) at $\lambda 200-750$ $\mathrm{nm}$

Table 3. The total anthocyanins content of methanol extract of parijoto fruit

\begin{tabular}{lc}
\hline Extract & Anthocyanins (mg . L-1) \\
\hline Pericarp & $208.75 \pm 1.65 \mathrm{a}$ \\
Whole fruit & $173.7 \pm 0.00 \mathrm{~b}$ \\
\hline
\end{tabular}

Table 4. The MDA level of hyperlipidemic rats treated with methanol extract of parijoto whole fruit

\begin{tabular}{cc}
\hline Group of animal & $\begin{array}{c}\text { MDA level on serum of hyperlipidemic } \\
\text { rats treated with methanol extract of } \\
\text { parijoto whole fruit (nmol . mL-1) }\end{array}$ \\
\hline I & $12.76 \pm 1.13 \mathrm{~b}$ \\
II & $14.88 \pm 2.03 \mathrm{a}$ \\
III & $9.89 \pm 0.32 \mathrm{c}$ \\
IV & $8.63 \pm 0.16 \mathrm{c}$ \\
V & $8.69 \pm 0.57 \mathrm{c}$ \\
\hline
\end{tabular}

\section{The MDA level of hyperlipidemic rats treated with the methanol extract of parijoto}

The results in Table 4 showed that the intake of a high lipid diet for 30 days increased blood serum MDA levels to $14.88 \mathrm{nmol}^{-1} \mathrm{~mL}^{-1}$. MDA is the main metabolite of arachidonic acid and serves as a reliable biomarker for oxidative stress (Singh et al. 2014). So that, high MDA levels indicate that ROS levels and its activity are also high. Table 4 showed that administration of parijoto methanol extracts affected MDA levels in blood serum. The administration of parijoto extracts reduced significantly ( $p<0.01$ ) MDA level in the blood serum of hyperlipidemic rats ( $R$. norvegicus) to $8.63-9.89 \mathrm{nmol}^{\mathrm{mL}}$ 1 , this might be due to the anthocyanins content of the extract. Anthocyanin has been known to have antioxidant activities.

\section{Discussion}

The total anthocyanins level of methanolic extract of parijoto

Parijoto (M. speciosa) has a purplish red color, which indicates that parijoto fruits contain anthocyanins.
Anthocyanins are polyphenols which have been known to have antioxidant activity, may affect several biological activities including preventing or reducing the risk of cardiovascular disease, diabetes, arthritis and cancer (Miguel 2011). Sa'adah et al. $(2017 ; 2018)$ reported that administration of parijoto methanol extract reduced total cholesterol, atherogenic index, LDL-C, triglycerides (TG) and increased HDL-C significantly ( $\mathrm{p}<0.01)$.

The results showed that the pericarp had a higher anthocyanin content than whole fruit of parijoto. The extract of parijoto pericarp has purplish red with darker color intensity than the whole fruit. The darker color intensity of extract could be an indication of higher anthocyanin content because the purple pigment was only found in the pericarp of parijoto.

Qualitative determination of anthocyanins was done by measuring the absorbance at the wavelength of 200-750 nm to the dissolved sample in different $\mathrm{pH}$ buffer conditions. Anthocyanin pigments undergo reversible structural transformations by the change of $\mathrm{pH}$ manifested by strikingly different absorbance spectra (Figure 3). Substantial quantitative and qualitative information can be obtained from the spectral characteristics of anthocyanins (Giusti and Wrolstad 2001).

One of the factors affecting anthocyanin pigments stability is $\mathrm{pH}$, which related to color, equilibrium forms and copigmentation (Jordheim 2007). At pH 1, the form of colored oxonium was dominant while at $\mathrm{pH} 4.5$ the dominant form was colorless hemiketal (Figure 4) (Giusti and Wrolstad 2001). In strong acid conditions $(\mathrm{pH}<2)$ the anthocyanins pigments are in the form of colored cations flavylium or oxonium, and the result of absorbance shows large amounts of anthocyanin (Suzery et al. 2010). The predominant of flavynium cation gives rise to a red color in anthocyanin solutions. At $\mathrm{pH} 4.5$ or weakly acidic conditions, the flavylium cation form changes slowly or rapidly to a more stable colorless hemiketal (alternatively hemiacetal or carbinol pseudo base) and chalcone form (Jordheim 2007). In aqueous solutions that are slightly acidic or neutral, anthocyanins are present as quinonoidal bases that are neutral and ionized after deprotonation. By hydration in weakly acidic solutions, the flavylium cation 
form is more or less rapidly transformed into a more stable hemiketal and colorless chalcone form (Jordheim 2007). The difference in absorbance between two buffer solutions corresponds to the monomeric anthocyanin pigment (Table 3 ). The pH-differential method allows an accurate and rapid measurement of the total anthocyanins, even in the presence of polymerized degraded pigments and other interfering compounds (Giusti and Wrolstad 2001).

The total anthocyanins content of methanol extract of parijoto pericarp and the whole fruit were calculated as Cyanidin 3-glucoside. Aguirre et al. (2016) reported that red to blue fruits are major dietary sources of anthocyanins (up to $1 \mathrm{~g} / 100 \mathrm{~g} \mathrm{FW}$ ), being cyanidin-3-O-glucoside $(\mathrm{Cy} 3 \mathrm{G})$ as the most widely distributed. $\mathrm{Cy} 3 \mathrm{G}$ confers a red hue to fruits. However, its content in raspberries and strawberries is low. In this study, the total anthocyanin content of parijoto whole fruits was lower than parijoto pericarp because the purple pigment is only found in the parijoto pericarp. Anthocyanins are known to be responsible for most red, blue, and purple colors and are mainly distributed among flowers, fruits, and vegetables (Gouvêa et al. 2012). The anthocyanin content of parijoto pericarp is higher compared other fruits such as strawberries $\quad(45-70 \mathrm{mg} / 100 \mathrm{~g})$, cranberries $\quad(45-100$ $\mathrm{mg} / 100 \mathrm{~g}$ ), sour cherries $(45 \mathrm{mg} / 100 \mathrm{~g}$ ), muscadine grapes (40-403 mg/100g), and raspberries (20-60 mg/100g) all based on wet weight (Gross 1987).

Anthocyanins were incorporated into the human diet many centuries ago and as components of the traditional herbal medicines (Konczak and Zhang 2004). Anthocyanin-rich food sources are in high demand because of its health benefits. The consumption of anthocyanins reduces the risk of cardiovascular disease, diabetes, arthritis, and cancer, due to their antioxidant, and antiinflammatory properties (Miguel 2011). Consumption of anthocyanin-rich fruits, extracts or pure compounds has proved to be effective in preventing or suppressing diseased states (McDougall et al. 2005; Miguel 2011). In the US, the addition of anthocyanins (180-215 mg/day) is much higher than the recommended (??) intake daily (23 $\mathrm{mg}$ /day), showing encouraging results in the treatment of cardiac diseases (Pervaiz et al. 2017). Therefore, parijoto was expected to be an alternative source of functional food products that has additional positive health benefits, both in short-and long-term health benefits (Cencic and Chingwaru 2010).

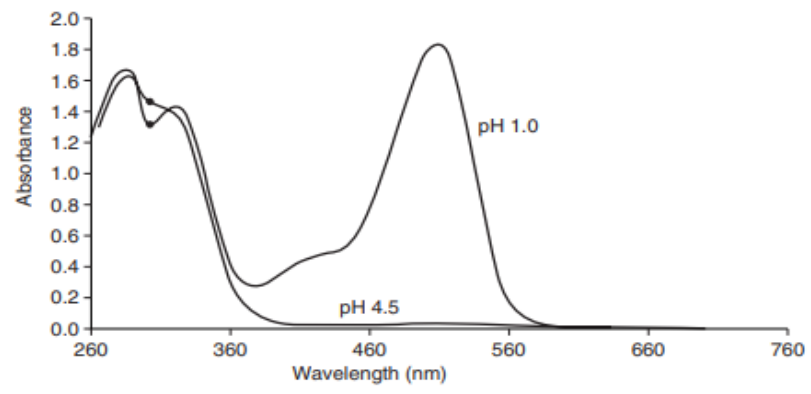

Figure 3. Spectral characteristics of purified radish anthocyanins (acylated pelargonidin-3-sophoroside-5-glucoside derivatives) in pH 1.0 and pH 4.5 buffers (Giusti and Wrolstad 2001)<smiles>[R]C1=CC(=C2Oc3cc(O)cc(O)c3C=C2O[Na])C=C([R])C1=O</smiles>

quinonoidal base: blue $\mathrm{pH}=7$

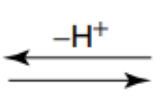<smiles></smiles>

flavylium cation (oxonium form): orange to purple $\mathrm{pH}=1$<smiles>[R]c1cc(C2(O)Oc3cc(O)cc(O[Na])c3C=C2O[Na])cc([18OH])c1O</smiles>

carbinol pseudo-base (hemiketal form): colorless $\mathrm{pH}=4.5$

Figure 4. Predominant structural forms of anthocyanins present at different pH levels (Giusti and Wrolstad 2001) 


\section{The effects of methanol extract of parijoto on MDA level of hyperlipidemic rats}

The intake of a high lipid diet for 30 days increased MDA levels in blood serum (Table 4). The high lipid dietinduced hypercholesterolemia result in increasing detrimental effects such as oxidative stress, inhibition of nitric oxide synthesis, and LDL conversion to oxidized LDL (OxLDL) (Khorrami et al. 2018). Further hypercholesterolemia was associated with glucoseautooxidation, thus leading to excess production of lipid peroxidation products which may cause elevation of oxidative stress in higher lipid and hyperlipidemic subjects (Yang et al. 2008). Other study reported that hypercholesterolemia leads to the production of oxygen free radicals, which exert their cytotoxic effect by causing lipid peroxidation, a chain reaction that occurs during oxidative stress leading to the formation of various active compounds including malondialdehyde (MDA) which can cause cellular damage. MDA is a mutagenic, tumorigenic and highly reactive three-carbon dialdehyde produced during polyunsaturated fatty acid peroxidation and arachidonic acid metabolism (Singh et al. 2014).

Monitoring MDA levels in different biological systems can be used as an important indicator of lipid peroxidation both in-vitro and in-vivo in various health disorders. Determination of MDA in blood plasma or tissue homogenates is one of the useful methods for predicting the oxidative stress levels, so MDA serves as a reliable biomarker for oxidative stress in biomedical fields (Singh et al. 2014). High MDA levels indicate that ROS levels and activity are also high. Elevating MDA levels after intake of a high lipid diet for 30 days in this research are indicating overproduction of free radicals and leading to lipid peroxidation and cell oxidative injury. The imbalance between the production of reactive oxygen species and antioxidant defense activity and its enhanced state has been associated with many of the chronic diseases such as cancer, diabetes, neurodegenerative and cardiovascular diseases called oxidative stress conditions (White et al. 2014). A higher level of MDA has been reported to plays a role in atherogenesis in rabbit aortae, a positive correlation between atheromatous lesions and MDA (Jeny et al. 1986). High levels of MDA were also found in lung cancer patients, hypertensive patients (Armas et al. 2007), the course of circulatory shock in human muscular tissue (Sahin et al. 2001), and recorded in HIV positive subjects in Kano state, Nigeria (Gwazo and Muhammad 2010).

Table 4 showed that administration of parijoto methanol extract affected the blood serum MDA levels. The administration of parijoto extract reduced significantly ( $p$ $<0.01)$ the blood serum MDA levels of hyperlipidemic rats ( $R$. norvegicus). Methanol extract of parijoto has a high total anthocyanins, which function primarily as antioxidant to overcome lipid peroxidation of cell membranes and its phenolic structure is dependable for antioxidant actions; i.e., capability to search reactive oxygen species (ROS) such as superoxide $\left(\mathrm{O}_{2}{ }^{*-}\right)$, peroxide (ROO-), singlet oxygen $\left(\mathrm{O}_{2}\right)$, hydroxyl radical $\left(\mathrm{OH}^{*}.\right)$ and hydrogen peroxide $\left(\mathrm{H}_{2} \mathrm{O}_{2}\right)$ (Pervaiz et al. 2017).
Antioxidants are an inhibitor of the oxidation process even at relatively small concentrations and have a diverse physiological role in the body (Kumar 2014). Antioxidants perform by delaying, preventing or removing oxidative damage to a target molecule (Shebis et al. 2013). Generally, the antioxidant activity of anthocyanins is associated with the number of free hydroxyls around the pyrone ring, where a greater number of hydroxyls increases antioxidant activity. Anthocyanins with their 3',4'dihydroxy groups can chelate metal ions quickly to form stable anthocyanin-metal complexes. Anthocyanins with ortho-dihydroxyl groups have the potential to scavenge hydroxyl radicals by inhibiting $\mathrm{HO}^{*}$ generation by chelating iron (Miguel 2011).

Anthocyanins belong to a large group of compounds collectively known as flavonoids, which are a subgroup of an even larger group of compounds known as polyphenols (Kamiloglu et al. 2015). Flavonoids can chelate free radicals immediately by donating a hydrogen atom or by single-electron transfer (Banjarnahor and Artanti 2014). Another possible mechanism of action of flavonoids is through the chelation of transition metal elements. Certain flavonoids have the potential capacity to chelate trace metal ions such as $\mathrm{Fe}^{2+}$ and $\mathrm{Cu}^{+}$that play a vital role in oxygen metabolism and free radical formation (Maleśev et al. 2007). Besides, flavonoids can also act as an intracellular antioxidant through inhibition of free radical generating enzymes such as xanthine oxidase, lipoxygenase, protein kinase $\mathrm{C}$, cyclooxygenase, microsomal monooxygenase, mitochondrial succinoxidase, and NADPH oxidase (Bubols et al. 2013).

\section{ACKNOWLEDGEMENTS}

The authors are gratefully express thanks to the Department of Biology and Institut Teknologi Sepuluh Nopember (ITS) Surabaya for financial support; Zoology and Animal Engineering Laboratory, Biology Department, ITS Surabaya; Experimental Animal Laboratory, Faculty of Pharmacy; and Biochemistry Laboratory, Faculty of Medicine, Universitas Airlangga for materials and technical assistance.

\section{REFERENCES}

Aguirre FJO, Rodrigo-García J, del R. Martínez-Ruiz N, Cárdenas-Robles AI, Mendoza-Díaz SO, Álvarez-Parrilla E, González-Aguilar GA, de la Rosa LA, Ramos-Jiménez A, Wall-Medrano A. 2016. Cyanidin-3O-glucoside: Physical-Chemistry, Foodomics and Health Effects. Molecules 21: 1264

Armas-Padilla MC, Armas-Hernandez MJ, Sosa Canache B, Cammarata R, Pacheco B, Guerrero J, Carvajal AR, Hernández-Hernández R, Israili ZH, Valasco M. 2007. Nitric oxide and malondialdehyde in human hypertension. Am J Ther 14: 172-176.

Banjarnahor SDS, ArtantiN. 2014. Antioxidant properties of flavonoids. Med J Indon 23 (4): 239-244.

Bubols GB, Vianna DR, Medina-Remon A, von Poser G, LamuelaRaventos RM, Eifler-Lima VL. 2013. The antioxidant activity of coumarins and flavonoids. Mini Rev Med Chem 13 (3): 318-34.

Cabrita L. 1999. Analysis and Stability of Anthocyanins. [Dissertation]. Dept. of Chemistry, University of Bergen, Bergen, Norway 
Cencic A, Chingwaru W. 2010. The role of functional foods, nutraceuticals, and food supplements in intestinal health. Nutrients 2 : 611-625.

Directive 2010/63/EU of the European Parliament and of the Council of 22 September 2010 on the protection of animals used for scientific purposes. http://eur-lex.europa.eu/legal-content/EN/ TXT/?uri=CELEX:32010L0063

Francis FJ. 1989. Food colorants: anthocyanins. Crit Rev Food Sci Nutr 28: 273-314.

Giusti MM, Wrolstad RE. 2011. Characterization and Measurement of Anthocyanins by UV-Visible Spectroscopy. Current Protocols in Food Analytical Chemistry F1.2.1-F1.2.13.

Gouvêa ACMS, de Araujo MCP, Schulz DF, Pacheco S, de O Godoy RL, Cabral LMC. 2012. Anthocyanins standards (cyanidin-3-O-glucoside and cyanidin-3-O-rutinoside) isolation from freeze-dried açaí (Euterpe oleraceae Mart.) by HPLC. Ciênc Tecnol Aliment Campinas 32 (1): 43-46.

Gross J. 1987. Pigments in Fruits. Academic Press, London.

Gwarzo MY, Muhammad SA. 2010. Extracellular superoxide dismutase activity and plasma malondialdehyde in human immunodeficiency virus subjects of Kano state as surrogate markers of CD4 status. Intl J Biomed Sci 6: 294-300.

Harborne JB. 1958. Spectral methods of characterizing anthocyanins. Biochem. J. 70: 22-28.

Iacobucci GA, Sweeny JG. 1983. The chemistry of anthocyanins, anthocyanidins and related flavylium salts. Tetrahedron 39: 30053038 .

Jaganath IB, Crozier A. 2010. Dietary flavonoids and phenolic compounds. In: Fraga CG (ed.). Plant Phenolics and Human Health: Biochemistry, Nutrition, and Pharmacology. John Wiley \& Sons, Inc. Hoboken, New Jersey.

Jeny C, Goy J, Fechner J, Loeper J, Emerit J. 1986. Study of lipid peroxidation by the assay of malondialdehyde in human and experimental atheroma. Presse Med 15: 1131-1133.

Jordheim M. 2007. Isolation, Identification and Properties of Pyranoanthocyanins and Anthocyanin Forms. [Dissertation]. Department of Chemistry, University of Bergen, Bergen. [Norway]

Juniarka IGA, Lukitaningsih E, Noegrohati S. 2011. Analisis aktivitas antioksidan dan kandungan antosianin total ekstrak dan liposom kelopak bunga rosella (Hibiscus sabdariffa L.). Majalah Obat Tradisional 16 (3): 115-123. [Indonesian]

Kamiloglu S, Capanoglu E, Grootaert C, Camp JV. 2015. Anthocyanin Absorption and Metabolism by Human Intestinal Caco-2 Cells-A Review. Intl J Mol Sci 16: 21555-21574.

Kasote DM, Katyare SS, Hegde MV, Bae H. 2015. Significance of antioxidant potential of plants and its relevance to therapeutic applications. Intl J Biol Sci 11 (8): 982-991.

Khorrami A, Garjani A, Bagheri B, Maleki-Dizaji N, Ziaee M. 2018. Comparison of the effects of hypercholesterolemic diets on biochemical outcomes of myocardial infarction in rats. Int Cardiovasc Res J 12 (1): 22-28.

Konczak I, Zhang W. 2004. Anthocyanins-More than nature's colours. J Biomed Biotechnol 5: 239-240.

Kumar S. 2014. The Importance of Antioxidant and Their Role in Pharmaceutical Science-A Review. Asian J Res Chem Pharmaceut Sci 1 (1): 27-44

Latifa KI. 2015. Profil Kadar MDA (Malondialdehide) pada Tikus yang Diberikan Ekstrak Herba Thymi (Thymus vulgaris L.). [Hon. Thesis] Fakultas Farmasi, Universitas Muhammadiyah Surakarta, Surakarta. [Indonesian]
Lestario LN, Rahayuni E, Timotius KH. 2011. Kandungan antosianin dan identifikasi antosianidin dari kulit buah Jenitri (Elaeocarpus angustifolius Blume). AGRITECH 31 (2): 93-101.

Maleśev D, Kunti V. 2007. Investigation of metal-flavonoid chelates and the determination of flavonoids via metalflavonoid complexing reactions. J Serb Chem Soc. 72 (10): 921-939.

Mazza GJ. 2007. Anthocyanins and heart health. Ann Ist Super Sanita 43 (4): 369-74

McDougall GJ, Dobson P, Smith P, Blake A, Stewart D. 2005. Assessing potential bioavailability of raspberry anthocyanins using an in vitro digestion system. J Agric Food Chem 53: 5896-5904.

Miguel MG. 2011. Anthocyanins: Antioxidant and/or anti-inflammatory activities. J Appl Pharmaceut Sci 1 (6): 7-15

Nakajima JI, Tanaka I, Seo S, Yamazaki M, Saito K. 2004. J Biomed Biotechnol 5: 241-247.

Pervaiz T, Songtao J, Faghihi F, Haider MS, Fang J. 2017. Naturally occurring anthocyanin, structure, functions and biosynthetic pathway in fruit plants. J Plant Biochem Physiol 2017, 5:2. DOI: 10.4172/2329-9029.100

Rintelen KV, Arida E, Häuse C. 2017. A review of biodiversity-related issues and challenges in megadiverse Indonesia and other Southeast Asian countries. Research Ideas and Outcomes 3: e20860. DOI: 10.3897/rio.3.e20860.

Sa'adah MM, Purwani KI, Nurhayati APD. 2017. Analysis of lipid profile and atherogenic index in hyperlipidemic rat (Rattus norvegicus Berkenhout, 1769) that given the methanolic extract of Parijoto (Medinilla speciosa). AIP Conference Proceedings 1854, 020031 (2017); https://doi.org/10.1063/1.4985422.

Sa'adah NN, Nurhayati APD, Purwani KI. 2018. Antihyperlipidemic and anti-obesity effects of the methanolic extract of parijoto (Medinilla speciosa). AIP Conference Proceedings 2002, 020046 (2018); DOI: $10.1063 / 1.5050142$.

Sahin U, Unlu M, Ozgumer MF, Taahan V, Akkaya A. 2001. Lipid peroxidation and erythrocyte superoxide dismutase activity in primary lung cancer. Biomed Res 12: 13-16.

Shebis Y, Iluz D, Kinel-Tahan Y, Dubinsky Z, Yehoshua Y. 2013. Natural antioxidants: function and sources. Food Nutr Sci 4: 643-649.

Singh Z, Karthigesu IP, Singh P, Kaur R. 2014. Use of malondialdehyde as a biomarker for assessing oxidative stress in different disease pathologies: A review. Iranian J Publ Health 43 (3): 7-16.

Suzery M, Lestari S, Cahyono B. 2010. Penentuan total antosiain dari kelopak bunga rosela (Hibiscus sabdariffa L.) dengan metode maserasi dan sokshletasi. Jurnal Sains dan Matematika 18 (1): 1-6. [Indonesian]

Tusanti I, Johan A, Kisdjamiatun RA. 2014. Sitotoksisitas in vitro ekstrak etanolik buah parijoto (Medinilla speciosa, reinw.ex bl.) terhadap sel kanker payudara T47D. Jurnal Gizi Indonesia 2 (2): 53-58. [Indonesian]

Wachidah LN. 2013. Uji aktivitas antioksidan serta penentuan kandungan fenolat dan flavonoid total dari buah parijoto: Medinilla speciosa Blume. [Hon. Thesis]. Program Studi Farmasi, UIN Syarif Hidayatullah, Jakarta. [Indonesian]

White PAS, Oliveira RCM, Oliveira AP, Serafini MR, Araújo AAS, Gelain DP, Moreira JCF, Almeida JRGS, Quintans JSS, QuintansJunior LJ, Santos RMV. 2014. Antioxidant activity and mechanisms of action of natural compounds isolated from lichens: A systematic review. Molecules 19: 14496-14527.

Yang R, Shi Y, Hao G, Li W, Le G. 2008. Increasing oxidative stress with progressive hyperlipidemia in human: relation between malondialdehyde and atherogenic index. J Clin Biochem Nutr 43 (3): 154-158. 